\title{
The Reactions of Oxotitanium(IV) Tetraphenylporphyrin with Methyl Methacrylate Radicals: A DFT Study
}

\author{
Anna K. Friesen \\ Ufa Institute of Chemistry - Subdivision of the Ufa Federal Research Centre of the Russian Academy of Sciences, 450054 \\ Ufa, Russia \\ E-mail: friesenak@rambler.ru
}

\begin{abstract}
A theoretical analysis of potential reactions between oxotitanium(IV) tetraphenylporphyrin with methyl methacrylate radicals was made. The structures of possible products were calculated and the energies of their formation were estimated. The oxotitanium(IV) tetraphenylporphyrin ((TPP)Ti=O) and the $\mathrm{CH}_{3}-\mathrm{CH}_{2}-\mathrm{C}^{*}\left(\mathrm{CH}_{3}\right)\left(\mathrm{C}(\mathrm{O}) \mathrm{OCH}_{3}\right) \mathrm{radical}$, which simulated a poly(methyl methacrylate) propagating radical, were used as the model particles for quantumchemical calculations. It has been shown that addition of the radical to the titanium atom does not occur, among other reactions the addition of radical to the $O$ atom (extraligand) is the most likely process. As a result, the metal-centered radical (TPP)Ti-O-R is formed, which can act as a trap for other methyl methacrylate radicals. Such radical addition occurs on the opposite side from the extraligand. In the (TPP)Ti(OR)(R) product, the radical is added to the titanium atom not by the $C$ atom but by the $O$ atom of the carbonyl group. Furthermore, it has been shown that $\beta$-H transfer does not occur with participation of the titanium atom belonging to $(T P P) T i=O$, but is principally possible with involvement of the extraligand. The $\beta$-H transfer involving the titanium atom in (TPP)T ${ }^{*}-O-R$ is energetically unfavorable.
\end{abstract}

Keywords: Oxotitanium(IV) tetraphenylporphyrin, methyl methacrylate radical, controlled radical polymerization, DFT calculations.

\section{Взаимодействие титанилового комплекса мезо-тетрафенилпорфирина с метилметакрилатными радикалами: DFT исследование}

\author{
А. К. Фризен \\ Уфимский Институт химии - обособленное структурное подразделение Федерального государственного \\ бюджетного научного учреждения Уфимского федерального исследовательского ичентра Российской академии \\ наук, 450054 Уфа, Россия \\ E-mail: friesenak@rambler.ru
}

\begin{abstract}
В настоящеей работе впервые проведен теоретический анализ потенциально возможных реакций между титаниловым комплексом мезо-замещенного порфирина и метилметакрилатными радикалами - рассчитано строение возможных продуктов и оценена энергетика их образования. Эти даннье отсутствуют в литературе, однако они необходимы для понимания механизма радикальной полимеризации, протекающей в присутствии указанного металлопорфирина. В качестве модельных частии для проведения квантово-химических расчетов использованы титаниловый комплекс мезо-тетрафенилпорфирина ((ТРP)Ті=O) и радикал $\mathrm{CH}_{3}-\mathrm{CH}_{2}-\mathrm{C}^{\cdot}\left(\mathrm{CH}_{3}\right)\left(\mathrm{C}(\mathrm{O}) \mathrm{OCH}_{3}\right)$, моделируюший радикал роста. Показано, что присоединение радикала по атому титана не идет, а среди остальных реакций наиболее вероятным процессом является присоединение радикала по атомукислорода (экстралиганду). В результате образуется металлоцентрированный радикал (TPP)Ti-O-R, способный выступать в качестве ловушки для других метилметакрилатных радикалов. Такое присоединение радикала идет с противоположной стороны от экстралиганда, причем в продукте (TPP)Ti(OR)(R) радикал присоединяется по атому титана не атомом углерода, а атомом кислорода карбонильной группь. Кроме того, показано, что перенос $\beta$-Н атома не идёт с участием атома титана, принадлежащего (TPP)Тi=O,
\end{abstract}


но в принципе возможен с участием экстралиганда. Перенос $\beta$-Н атома с участием атома титана, принадлежащего (ТРP)Ti-O-R, энергетически невыгоден.

Ключевые слова: Титаниловый комплекс, мезо-тетрафенилпорфирин, метилметакрилатный радикал, контролируемая радикальная полимеризация, теория функционала плотности.

\section{Introduction}

Metal complexes of porphyrins attract attention of researchers in many areas. ${ }^{[1]}$ In polymer chemistry, the interest in these complexes results from the possibility to use them as catalysts or initiators of controlled polymerization processes. ${ }^{[1-3]}$ The possibility to use metalloporphyrins for controlled synthesis of macromolecules was discovered rather long ago, ${ }^{[2]}$ and the mechanism of the action of many metalloporphyrins containing nontransition metals on polymerization processes has been fairly well studied to date. ${ }^{[1]}$ In the case of metalloporphyrins containing transition metal atoms, the range of compounds studied as components of polymerization mixtures is much narrower. In the latter case, the attention of researchers is mainly focused on the processes of catalytic chain transfer and catalytic inhibition that occur on cobalt- and rhodiumcontaining porphyrins..$^{[1-3]}$

As concerns oxotitanium(IV) porphyrins, there are very few experimental studies on their effect on radical polymerization, ${ }^{[4,5]}$ while theoretical studies in this field are absent altogether. Thus, many aspects of the action mechanism of Ti-containing porphyrins in polymerization processes have not been studied to date.

An experimental study of the effect of oxotitanium complexes of meso-substituted porphyrins with the formula $\mathrm{LTi}=\mathrm{O} \quad$ (where $\mathrm{L}=5,10,15,20$-tetrakis(3',5'-di-tert-butylphenyl)porphyrin or 5,10,15,20-tetrakis(3'-butoxyphenyl) porphyrin) on the radical polymerization of methyl methacrylate (MMA) was reported previously. ${ }^{[4,5]}$ It was shown that they affected the process kinetics and the molecular mass characteristics of the resulting polymers, and the assumption was made that the process occurred by a complex-radical mechanism. Based on these experiments, it was assumed that $\mathrm{LT} i=\mathrm{O}$ can participate in all stages of the polymerization process, viz., initiation, termination, and even chain growth: it was assumed that monomer addition to the growth radical can occur in the Ti coordination sphere. However, it is difficult to identify the process mechanism solely based on experimental data. For example, it remained unclear whether propagating radicals (or monomer molecules) can coordinate to the metal atom in oxotitanium(IV) porphyrins, since the Ti atom is coordination-saturated there. It is unknown whether any other radical adducts can be formed in reactions of a metalloporphyrin with radicals present in a polymerizing mixture. If yes, then what is the spin density distribution in these adducts: are they relatively stable radicals with delocalized spin density, or are they highly reactive intermediates? What further reactions involving them are possible in a polymerizing system, and how will it affect the process rate and the properties of the polymer formed? These questions are also interesting in the context of the synthesis of porphyrin-containing polymers ${ }^{[6]}$ since metalloporphyrins within macromolecules are potential "platforms" for the formation of donor-acceptor complexes, e.g., with fullerene molecules. This can be used to create solar cells, molecular switches, and other photoconductive materials.

Experimental studies of the mechanisms of elementary acts that occur in complex processes, such as radical polymerization, are difficult as the intermediates have low concentrations and high reactivity. On the other hand, the capabilities of modern computational chemistry can be used successfully for this purpose. ${ }^{[7,8]}$ Therefore, in this study were performed a quantum-chemical simulation of the possible pathways in a reaction of an oxotitanium(IV) porphyrin with methyl methacrylate radicals, estimated the energy characteristics of potential reactions, and analyzed the structure of the intermediates.

\section{Computational Details}

Quantum-chemical calculations were performed by means of Priroda-06 software ${ }^{[9,10]}$ that uses Gauss-type basis sets for solution of Kohn-Sham equations, as well as electron density decomposition in an auxiliary basis for calculating the Coulombic and exchange-correlation energy. The PBE density functional ${ }^{[1]}$ and a three-exponent basis set consisting of compacted orbital sets of Gaussian type functions, viz., (5s1p)/[3s1p] for $\mathrm{H},(11 \mathrm{~s} 6 \mathrm{p} 2 \mathrm{~d}) /$ [6s3p2d] for $\mathrm{C}$ and $\mathrm{O}$, and $(17 \mathrm{~s} 13 \mathrm{p} 8 \mathrm{~d}) /[12 \mathrm{~s} 9 \mathrm{p} 4 \mathrm{~d}]$ for $\mathrm{Ti}$, were used. The auxiliary basis sets are uncompressed sets of Gaussian type functions with sizes of $(5 \mathrm{~s} 2 \mathrm{p})$ for $\mathrm{H},(10 \mathrm{~s} 3 \mathrm{p} 3 \mathrm{~d} 1 \mathrm{f})$ for $\mathrm{C}$ and $\mathrm{O}$, and $(18 \mathrm{~s} 6 \mathrm{p} 6 \mathrm{~d} 5 \mathrm{f} 5 \mathrm{~g})$ for Ti. The unrestricted formulation was used for open-shell systems. The calculations were performed for the gas phase (because solvent polarity not affect significantly the barriers of radical reactions, so the gas-phase theoretical results are appropriate for modelling of studied process). Optimization of the geometric parameters of the structures studied was performed without symmetry restrictions. The calculation of molecular orbitals was performed by the MP2/6-311G(d,p) method using Gaussian'09 software ${ }^{[12]}$ by single-point calculation of structures whose geometry parameters were optimized by the PBE/3z method described above. The second derivatives were used to determine the type of stationary point. I used the oxotitanium(IV) tetraphenylporphyrin $((\mathrm{TPP}) \mathrm{Ti}=\mathrm{O})$ and the $\mathrm{CH}_{3}-\mathrm{CH}_{2}-\mathrm{C}^{\cdot}\left(\mathrm{CH}_{3}\right)(\mathrm{C}(\mathrm{O})$ $\mathrm{OCH}_{3}$ ) methyl methacrylate radical, which is designated as $\mathrm{R}$ in the text below, as the model particles. The method that I used well reproduces the structure of the oxotitanium(IV) porphyrin (see supporting materials). The energy parameters of the reactions studied (energy changes $(\Delta E)$, activation barriers) were calculated as the full energy differences between the reaction products (or reaction transition state) and the starting particles.

\section{Results and Discussion}

Taking into account the known data ${ }^{[13,14]}$ about the possible reactions between radicals and transition metal complexes during radical polymerization, as well as the struc- 
tures of the particles studied here, the following reactions should be simulated: 1) radical addition to the metal atom; 2) radical addition to the ligands (both to the porphyrin macrocycle and to the oxygen extraligand); 3) hydrogen atom transfer from the radical to the metalloporphyrin.

To identify the most reactive zones of the (TPP) $\mathrm{Ti}=\mathrm{O}$ molecule, its frontier molecular orbitals were calculated (Figure 1). Two LUMOs are degenerated in energy. Analysis of HOMO and LUMO shows that they are mainly local-

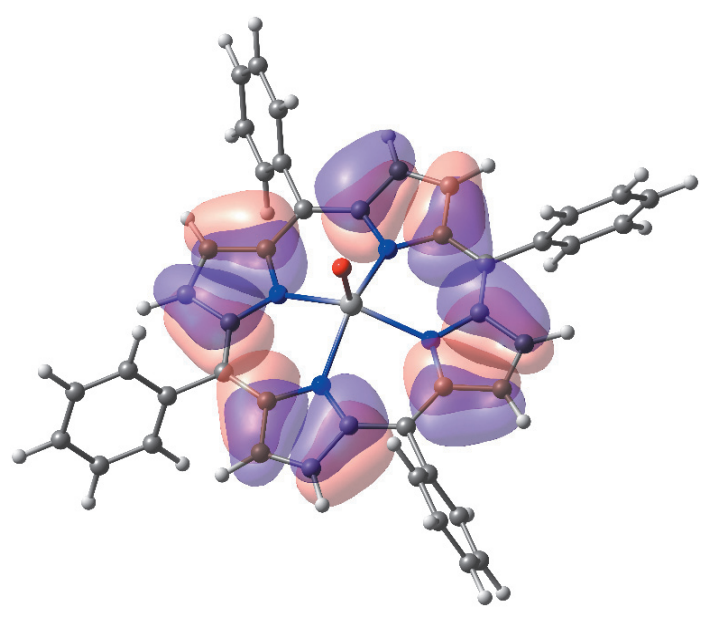

HOMO (-6.26 eV)

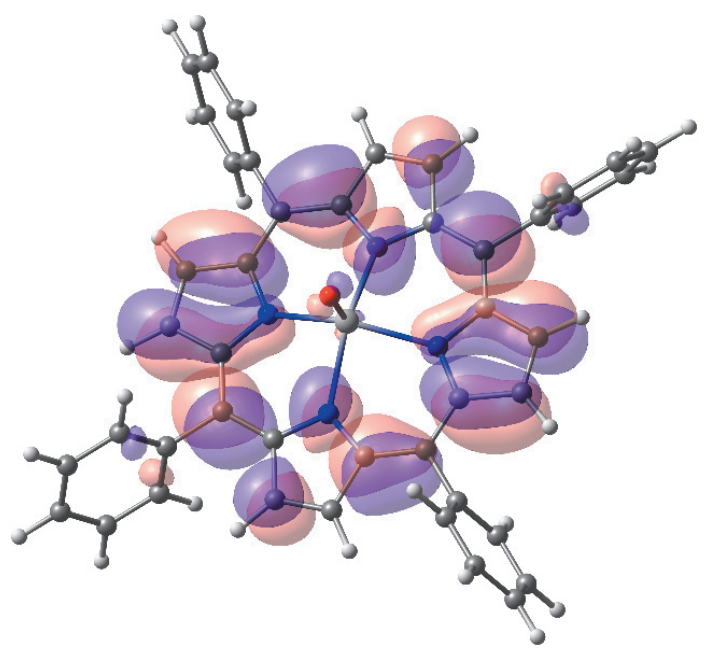

LUMO (-0.02 eV)



LUMO+1 $(-0.02 \mathrm{eV})$

Figure 1. Frontier molecular orbitals of the (TPP) $\mathrm{Ti}=\mathrm{O}$ molecule. ized on the porphyrin macrocycle and, to a small extent, on the oxygen extraligand (the corresponding contributions on the atoms are presented in supporting materials).

The molecular orbitals localized on the metal lie at rather high energies. Hence, it should be expected that the largest reactivity in the metalloporphyrin in question is possessed by the carbon atoms at the meso-positions of the porphyrin cycle and the $\mathrm{O}$ atom (the extraligand). It should however be noted that the $\mathrm{C}$ atoms of the porphyrin macrocycle which have the maximum contributions are shielded by the phenyl groups located at the mesopositions.

\section{Addition of $R^{\cdot}$ to the Ti Atom}

The methyl methacrylate radical can be represented as two resonance structures shown below:<smiles>CCCCCC</smiles>

Therefore, it was checked whether $\mathrm{R}^{*}$ can be coordinated to the titanium atom in two ways, i.e., through the tertiary $\mathrm{C}$ atom and through the $\mathrm{O}$ atom of the carbonyl group (in both cases, both on the opposite side from the extraligand and on the same side with it). However, attempts to scan the potential energy surface of the corresponding reactions did not reveal any stable products. Thus, the calculation results indicate that the methyl methacrylate radical is not added to the $\mathrm{Ti}$ atom in the (TPP) $\mathrm{Ti}=\mathrm{O}$ molecule.

\section{Addition of $R^{\cdot}$ to the $C$ Atoms of the Porphyrin Macrocycle}

The porphyrin ring of the metalloporphyrin being studied contains six non-equivalent $\mathrm{C}$ atoms; furthermore, the calculations took into account the possibility of radical addition both on the same side with the oxygen extraligand and on the opposite side from it. Only six structures were identified by calculations (1-6, Figure 2), since in some cases considerable steric hindrance exists or a too strong distortion of the macrocycle plane appears. In most cases, the formation of products of this type occurs with energy consumption and results in structures with spin density that is strongly delocalized over the carbon frame of the porphyrin macrocycle (the spin densities on the atoms are presented in supporting materials). For product 1 with the lowest energy, the activation barrier of its formation is $39.0 \mathrm{~kJ} / \mathrm{mol}$ (the data about the transition state (TS1) are presented in Supporting materials).

In products 1-3 which are most probable in terms of energy, the maximum spin density is about 0.30 a.u. and is localized on the $\mathrm{C}$ atom of the nearest methylene moiety of the porphyrin ligand. The maximum spin density in products 4-6 is localized on the $\mathrm{C}$ atom at the meso-position of the porphyrin ring and does not exceed 0.16 a.u. 


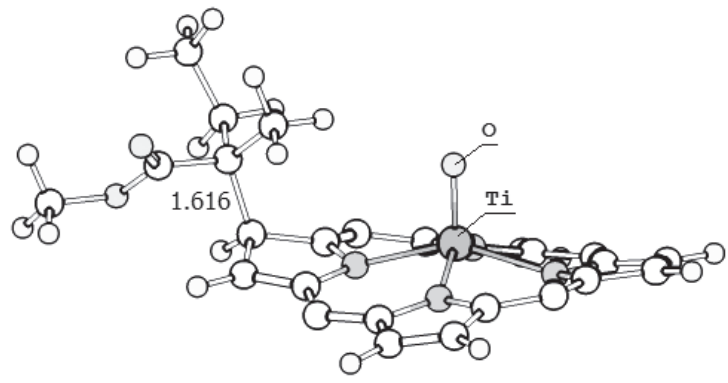

$\mathbf{1}\left(\Delta E=-1.9, E_{\text {rel }}=0\right)$

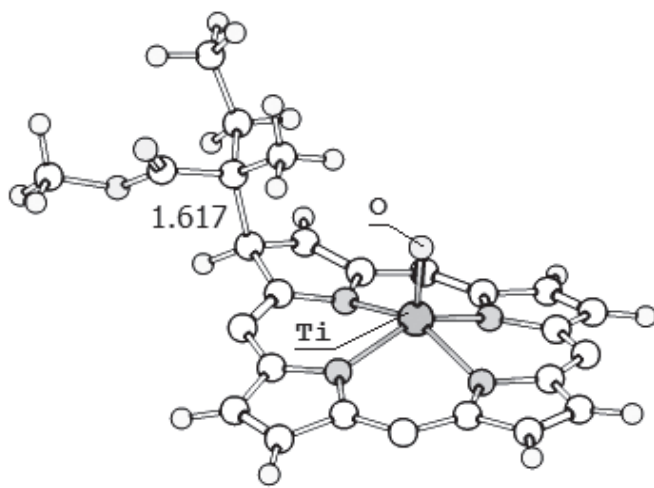

$3\left(\Delta E=3.1, E_{\mathrm{rel}}=5.0\right)$

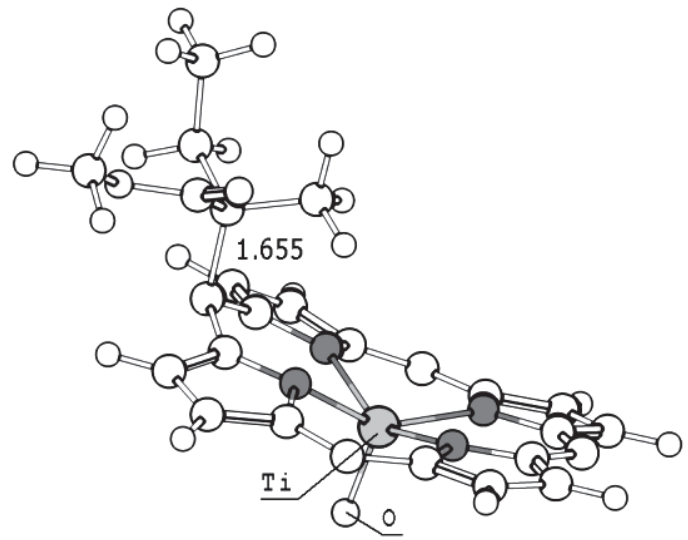

$5\left(\Delta E=42.6, E_{\mathrm{rel}}=44.5\right)$

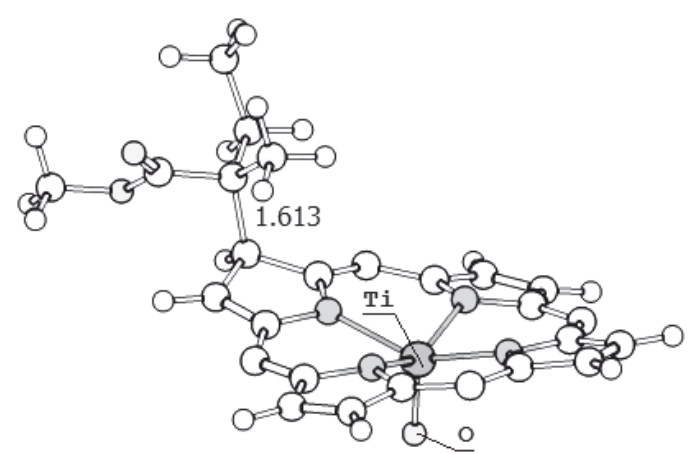

$\mathbf{2}\left(\Delta E=1.4, E_{\mathrm{rel}}=3.3\right)$



$4\left(\Delta E=36.2, E_{\text {rel }}=38.1\right)$

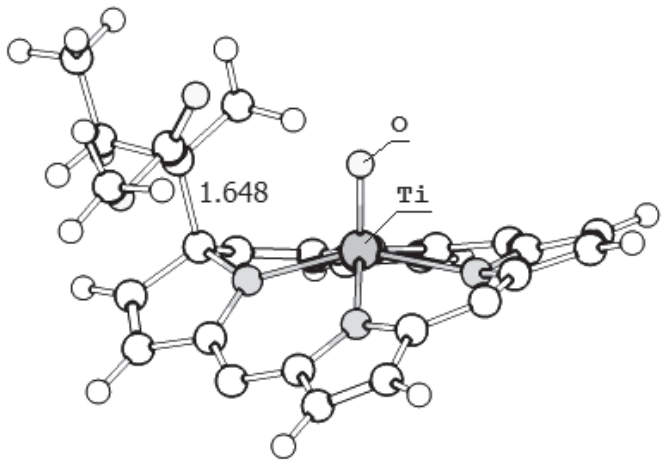

$6\left(\Delta E=90.7, E_{\text {rel }}=92.6\right)$

Figure 2. Structure of the products of addition of methyl methacrylate radical to carbon atoms of the porphyrin ring in (TPP)Ti=O and the calculated $\Delta E$ values of their formation (here and below, the values are in $\mathrm{kJ} / \mathrm{mol}$ ). Product $\mathbf{1}$ is taken as zero-level when the relative energies $\left(E_{\mathrm{rel}}\right)$ were calculated. Here and in the subsequent figures, the phenyl substituents at the meso-positions of the porphyrin ring are not shown.

\section{Reaction of $R^{\cdot}$ with the Extraligand}

The product of $\mathrm{R}^{\cdot}$ addition through the tertiary $\mathrm{C}$ atom to the oxygen extraligand of the (TPP) $\mathrm{Ti}=\mathrm{O}$ molecule is shown in Figure 3. Product 7, unlike products 1-6, is formed with liberation of a considerable energy. The activation energy of this reaction is $29.2 \mathrm{~kJ} / \mathrm{mol}$ (data on the transition state (TS2) are presented in Supporting materials). The spin density in structure 7 is mainly localized on the titanium atom and amounts to 0.65 a.u., hence it can be represented as (TPP)Ti--O-R.
In radical polymerization processes, cobalt porphyrins can be involved in catalytic chain transfer (reaction 2 in the scheme below) and catalytic inhibition (reaction 3$):[1-3,14]$

$$
\begin{aligned}
& \mathrm{R}_{\mathrm{n}}+\mathrm{Co}^{\bullet} \rightarrow \mathrm{P}_{\mathrm{n}}+\mathrm{Co}-\mathrm{H} \\
& \mathrm{Co}-\mathrm{H}+\mathrm{M} \rightarrow \mathrm{R}_{1} \cdot+\mathrm{Co}^{\bullet} \\
& \mathrm{Co}-\mathrm{H}+\mathrm{R}_{\mathrm{n}} \cdot \mathrm{Co}^{\bullet}+\mathrm{P}_{\mathrm{n}(=)}
\end{aligned}
$$




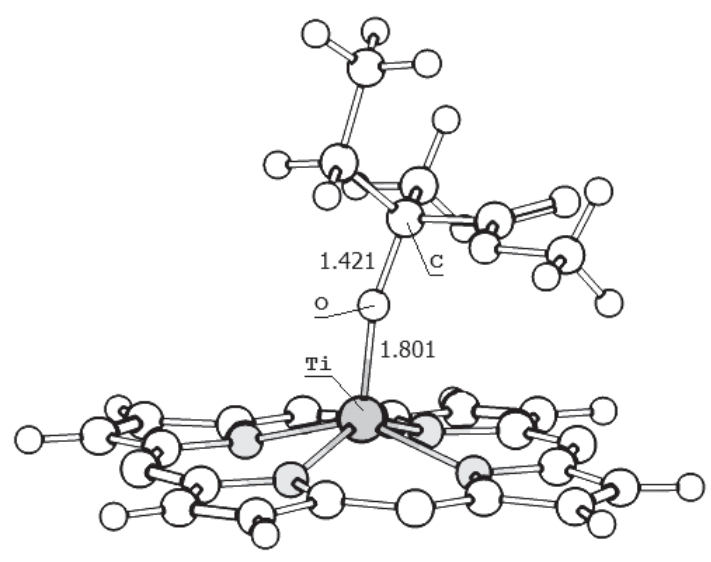

$7(\Delta E=-58.0)$

At first, the Co-H metal hydride is formed, which can then transfer the chain to a monomer (catalytic chain transfer, reaction 2) or terminate the growing chain (catalytic inhibition, reaction 3). In this study I tested the possibility of similar reactions involving (TPP) $\mathrm{Ti}=\mathrm{O}$, but no metal hydride structures were found by calculation. However, another process was found possible as $\mathrm{R}^{*}$ and (TPP) $\mathrm{Ti}=\mathrm{O}$ approach each other, namely, elimination of an $\mathrm{H}$ atom belonging to the methyl methacrylate radical by the extraligand. Scheme 1 shows the energy profiles of the reactions of $\mathrm{H}$ elimination from the methylene and methyl groups of the methyl methacrylate radical. One can see from Scheme 1 that the activation barriers of the processes in question are similar, but the first process $(\beta-\mathrm{H}$ transfer) is more probable. The structures of transition states TS3 and TS4 are shown in Figure 4.

\section{Reactions of (TPP)Ti-O-R and (TPP)Ti $-\mathrm{O}-\mathrm{H}$}

upon addition of the methyl methacrylate radical to the oxygen atom of (TPP) $\mathrm{Ti}=\mathrm{O}$ through the tertiary carbon atom.

Of the calculated pathways of the reactions of $\mathrm{R}^{\bullet}$ with the (TPP) $\mathrm{Ti}=\mathrm{O}$ molecule (see Supporting materials), the for-

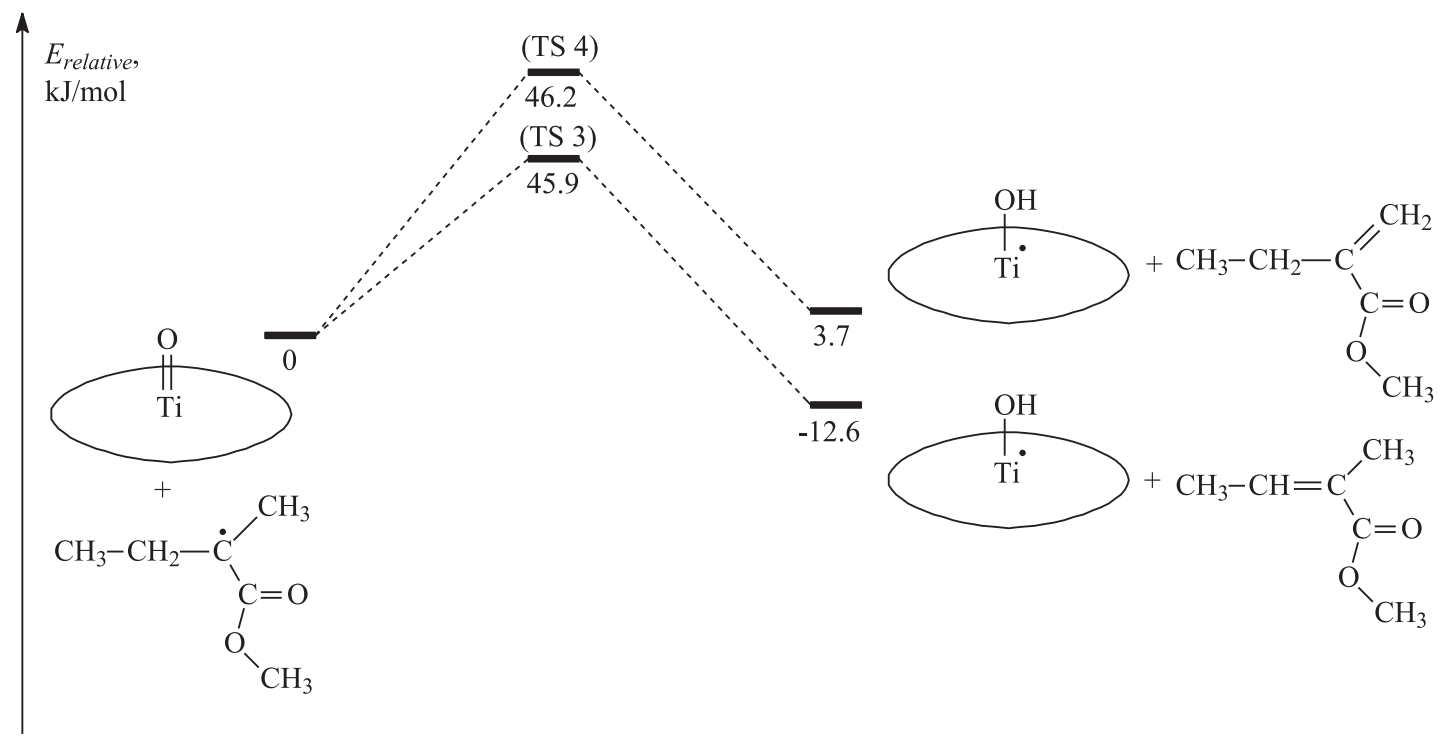

Scheme 1. Energy profile of reactions of $\mathrm{H}$ atom abstraction by the extraligand of (TPP) Ti=O molecule from the methyl methacrylate radical.



TS3

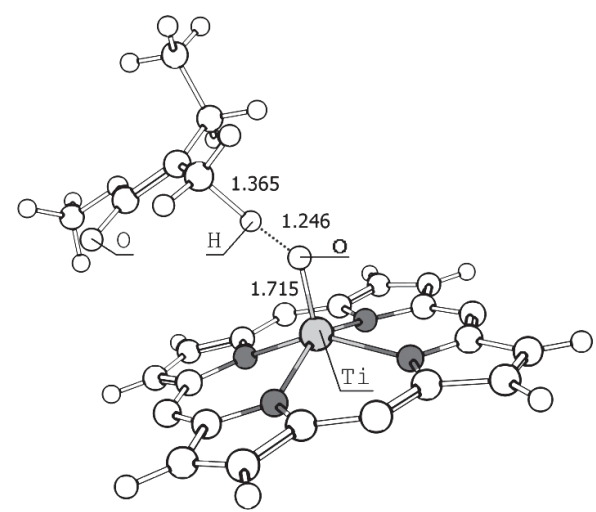

TS4

Figure 4. Structures of transition states of $H$ atom transfer from the methylene (TS3) and methyl (TS4) groups of methyl methacrylate radical to the oxygen extraligand of the oxotitanium(IV) tetraphenylporphyrin. 
mation of particle 7 ((TPP)Ti-O- $\mathrm{O})$ is most probable in terms of energy. Since such a metal-centered radical is a potential spin trap for propagating radicals (which matches the theory of controlled radical polymerization by the OMRP mechanism) ${ }^{[13]}$ I performed a simulation of $\mathrm{R}^{*}$ addition to the titanium atom in intermediate 7. According to the calculation results, no recombination product with a Ti-C bond is formed, but the methyl methacrylate radical can form a bond with a titanium atom through the $\mathrm{O}$ atom of the carbonyl group (product 8, Figure 5). This reaction results in evolution of $45.7 \mathrm{~kJ} / \mathrm{mol}$. According to the controlled radical polymerization theory, an efficient pseudo-living process occurring by the reversible recombination-dissociation mechanism ${ }^{[14]}$ requires that the binding of a growing chain with a trap be sufficiently strong in order to ensure prolonged existence of the chain in "dormant" form (note that where OMRP processes are discussed, the formation of a metal-carbon bond, rather than a metal-oxygen bond as in our case, is referred to). Obviously, in this case the bond strength of the radical with the trap is not high, therefore the process does not occur in controlled mode.



Figure 5. Structure of the product of methyl methacrylate radical addition through the $\mathrm{O}$ atom of the carbonyl group to the titanium atom in the (TPP) Ti- $-\mathrm{O}-\mathrm{R}$ intermediate.

It should be noted that, according to calculation results, the (TPP)Ti-O-O $\mathrm{R}$ is inactive toward the monomer molecules (MMA).

Since the energy barriers of the reactions of (TPP) Ti-O-O $-\mathrm{R}$ and (TPP)Ti-O-O formation are similar (which allows one to assume that both metal-centered radicals are present in the polymerization system), I also calculated the energy change upon formation of a recombination product of the methyl methacrylate radical with $(\mathrm{TPP}) \mathrm{Ti}-\mathrm{O}-\mathrm{H}((\mathrm{TPP}) \mathrm{Ti}(\mathrm{OH})(\mathrm{R})$ - product 9; its structure is similar to that of product $\mathbf{8}$, therefore it is not shown in the figure). The corresponding $\Delta E$ value was $-50.3 \mathrm{~kJ} / \mathrm{mol}$ (for the reaction (TPP) $\mathrm{Ti}^{-}-\mathrm{O}-\mathrm{H}+\mathrm{R}^{*} \rightarrow(\mathrm{TPP}) \mathrm{Ti}(\mathrm{OH})(\mathrm{R})$ ).

I also analyzed whether the (TPP)Ti-O $-\mathrm{R}$ metalcentered radical can form the (TPP)Ti(OR)(H) metal hydride due to abstraction of an $\mathrm{H}$ atom from the methyl methacrylate radical (by analogy with cobalt porphyrins, as mentioned above). ${ }^{[3]}$ According to the calculation results, this process is very unfavourable energetically: the $\beta-\mathrm{H}$ transfer occurs with consumption of $95.1 \mathrm{~kJ} / \mathrm{mol}$, while abstraction of an $\mathrm{H}$ atom from the $\alpha$-methyl group occurs with $\Delta E=111.3 \mathrm{~kJ} / \mathrm{mol}$. Similar reactions where the (TPP)Ti $(\mathrm{OH})(\mathrm{H})$ metal hydride is formed upon abstraction of $\mathrm{H}$ belonging to a methyl methacrylate radical by a titanium atom belonging to the (TPP) $\mathrm{Ti}^{\circ}-\mathrm{O}-\mathrm{H}$ particle is characterized by $\Delta E$ values of 87.3 and $103.6 \mathrm{~kJ} / \mathrm{mol}$.

\section{Discussion of the Possible Mechanism of Polymerization Process}

Previously it was assumed in literature based on experimental data $^{[4]}$ that methyl methacrylate polymerization in the presence of $\mathrm{LTi}=\mathrm{O}$ metalloporphyrins occurs by a complex-radical mechanism. This mechanism assumes the coordination of propagating radicals (and/ or monomer molecules) to the metal, ${ }^{[15,16]}$ which causes their polarization and consequent activation. However, unlike typical agents of complex-radical polymerization, viz., Lewis acids having vacant low-lying molecular orbitals on the metal atom, the frontier orbitals in the (TPP) $\mathrm{Ti}=\mathrm{O}$ molecule are not metal-centered. The attempts made in this study to simulate structures in which an MMA molecule is coordinated by the $\mathrm{O}$ atom of the carbonyl group to the titanium atom in (TPP) $\mathrm{Ti}=\mathrm{O}$ (both on the opposite side from the extraligand and on the same side with it) did not result in localization of stable complexes. The metalcentered (TPP)Ti- ${ }^{\circ} \mathrm{O}-\mathrm{R}$ radical, which according to calculation results can be formed in the polymerizing system, does not have an activating action toward the monomer, either. Thus, the results of calculations performed in this study indicate that MMA polymerization in the presence of oxotitanium(IV) porphyrin does not involve a complexradical mechanism.

These results agree with the experimental data ${ }^{[4,5]}$ on the effect of oxotitanium(IV) porphyrins on the radical polymerization of MMA and allow some of its features to be explained. For example, the molecular masses of poly(methyl methacrylate) (PMMA) synthesized in the presence of oxotitanium(IV) porphyrins with initiation by azobisisobutyronitrile nearly do not change. The microstructure of polymers does not change either, while the polydispersity indices of the resulting PMMA samples obtained decrease by approximately one unit. Apparently, the latter phenomenon can be explained by a small contribution of the reversible reaction

$$
\text { (TPP)Ti-O-R + R` } \leftrightarrow(\mathrm{TPP}) \mathrm{Ti}(\mathrm{OR})(\mathrm{R})
$$

to the overall process picture.

\section{Conclusions}

Thus, the following conclusions can be made on the basis of the calculations that I performed. During 
the radical polymerization of methyl methacrylate, propagating radicals can add to a molecule of oxotitanium(IV) porphyrin, the addition to the oxygen extraligand being the most likely mechanism. The product resulting from this addition is a metal-centered radical that can reversibly bind methyl methacrylate radicals. The strength of this binding is low, therefore the process does not occur in controlled mode. However, in experiments this is observed as a decrease in the polydispersity indices of the PMMA samples obtained. The main chain of the polymer synthesized in the presence of $(\mathrm{TPP}) \mathrm{Ti}=\mathrm{O}$ can contain titanium atoms, since calculations indicate that porphyrin-containing products (TPP)Ti(OR)(R) can be formed.

Acknowledgements. The calculations were performed using the equipment at the Center for collective use "Khimiya" (Chemistry) at Ufa Institute of Chemistry of the Russian Academy of Sciences within the State task for 2017-2019 (AAAA-A17-117011910026-3).

\section{References}

1. Applications: Past, Present and Future. In: The Porphyrin Handbook, Vol. 6 (Kadish K.M., Smith K.M., Guilard R., Eds.). New York: Academic Press, 2000.

2. Wayland B.B., Poszmik G., Mukerjee S. J. Am. Chem. Soc. 1994, 116, 7943-7944.
3. Heuts J.P.A., Forster D.J., Davis T.P. Mechanistic Aspects of Catalytic Chain Transfer Polymerization. In: Transition Metal Catalysis in Macromolecular Design, Chapter 16, p. 254-272.

4. Islamova R.M., Nazarova S.V., Koifman O.I. Macroheterocycles 2011, 4, 97-105.

5. Monakov Yu.B., Koifman O.I., Nasretdinova R.N., Islamova R.M., Puzin Yu.I., Ionova I.A. J. Balkan Tribol. Assoc. 2006, 12(3), 294-302.

6. Mironov A.F. Macroheterocycles 2011, 4, 186-208.

7. Friesen A.K., Ulitin N.V., Khursan S.L., Shiyan D.A., Tereshchenko K.A., Kolesov S.V. Mendeleev Commun. 2017, 27, 374-376.

8. Ulitin N.V., Tereshchenko K.A., Frizen A.K., Burakova A.O., Kolesov S.V., Shiyan D.A., Temnikova N.E. Kinet. Catal. 2017, 58, 122-132.

9. Laikov D.N., Ustynyuk Yu.A. Russ. Chem. Bull. 2005, 54, $820-826$.

10. Laikov D.N. Chem. Phys. Lett. 1997, 281, 151-156.

11. Perdew J.P., Burke K., Ernzerhof M. Phys. Rev. Lett. 1996, 77, 3865-3868.

12. Frisch M.J., Trucks G.W., Schlegel H.B., et. al. Gaussian 09, Revision D.01, Gaussian, Inc., Wallingford CT, 2013.

13. Poli R. Eur. J. Inorg. Chem. 2011, 1513-1530.

14. Handbook of Radical Polymerization. (Matyjaszewski K., Davis T.P., Eds.). John Wiley \& Sons, Inc. Publication. 2002. 920 p.

15. Bamford C.H., Jenkins A.D., Johnson R. Proc. R. Soc. London A 1957, 241, 364-375.

16. Zubov V.P., Valuev L.I., Kabanov V.A., Kargin V.A. J. Polym. Sci., A 1971, 9(4), 833-854. 